\title{
Obesity in Patient with Grown Up Congenital Heart Disease Ventricular Septal Defect with Pulmonary Hypertension in Sanglah Hospital, Bali, Indonesia
}

\author{
Nabila Natasya ${ }^{1, *}$, Maya Paramita Wijaya1, Yosi Kusuma1, I Made Putra Swi Antara² \\ ${ }^{1}$ Faculty of Medicine - Udayana University, Bali, Indonesia \\ ${ }^{2}$ Cardiovascular Medicine Department - Sanglah Hospital, Bali, Indonesia
}

${ }^{*}$ Corresponding author:

Nabila Natasya MD, - email: nabilanatasya@hotmail.com

Faculty of Medicine - Udayana University, Bali, Indonesia

Manuscript submitted: January 12, 2018; Revised and accepted: February 10, 2018

\begin{abstract}
Ventricular septal defect (VSD) is a congenital heart disease (CHD) which characterized by a hole in the wall that separate between the right and left ventricle. There are several types of VSD based on its location, which are perimembranous/conoventricular, subpulmonary/ conotruncal, supracristal/doubly commited, muscular and atrioventricular canal/inlet. A VSD is one of the most common CHD which occurs in approximately 2-6 of every 1,000 live births and accounts for more than $20 \%$ of all CHDs. However, the population of VSD patients with grown up congenital heart disease $(\mathrm{GUCH})$ is still uncertain. We are presenting a rare case of a 19 year old patient with congestive heart failure NYHA functional class IV due to uncorrected left-to-right shunt supracristal VSD with body mass index of $35.5 \mathrm{~kg} /$ $\mathrm{m}^{2}$. He presented in the emergency room with acute decompensated heart failure profile B. Echocardiography revealed decreased left ventricle (LV) systolic function, normal right ventricle (RV) systolic function, decreased LV diastolic function, and dilated left atrium and LV. We plan to perform right heart catheterisation and pulmonary artery oxygen responsiveness test followed by VSD closure in this patient. Another explanation will be discussed in this paper.
\end{abstract}

Keywords: supracristal VSD; GUCH; pulmonary hypertension; obesity

\section{INTISARI}

Defek septum ventrikel (DSV) adalah penyakit jantung bawaan (PJB) yang ditandai oleh adanya lubang pada dinding yang memisahkan antara ventrikel kanan dan kiri. Terdapat beberapa tipe DSV tergantung dari lokasinya, yaitu perimembran/konoventrikular, subpulmonal/konotrunkal, suprakrista/doubly committed, muskular dan kanal atrioventrikular/ inlet. DSV merupakan salah satu PJB yang sering ditemukan yaitu sekitar 2-6 dari setiap 1.000 kelahiran hidup dan menjadi $>20 \%$ dari seluruh PJB. Namun, populasi DSV pada dewasa dengan PJB belum diketahui. Kami melaporkan sebuah kasus jarang pasien 19 tahun dengan gagal jantung kongestif kelas fungsional NYHA IV karena DSV supracrista pirau kiri ke kanan yang tidak dikoreksi dengan indeks massa tubuh $35,5 \mathrm{~kg} / \mathrm{m}^{2}$ yang datang ke unit gawat darurat. Ekhokardiografi menunjukkan penurunan fungsi ventrikel kiri, fungsi sistolik ventrikel kanan normal, penurunan fungsi diastolik ventrikel kiri dengan dilatasi atrium kiri dan ventrikel kiri. Kami merencanakan tindakan kateterisasi jantung kanan, tes reaktifitas oksigen dan penutupan DSV pada pasien ini. Beberapa penjelasan akan dibahas dalam laporan kasus ini.

\section{INTRODUCTION}

Ventricular septal defect (VSD) is an acyanotic congenital heart disease (CHD) which results in left-to-right shunting. The changes in hemodynamic in patient with VSD depends on the size of the hole. A small restrictive VSD would result in high pressure gradient between the two ventricles and normally or mildly elevated 
pulmonary arterial pressure. On the other hand, a larger and nonrestrictive VSD would permit equalize gradient between the ventricle and high pulmonary arterial pressure. ${ }^{1}$ When this happened, the right ventricle, pulmonary artery, left atrial and left ventricle would experience a relative volume overload. Overtime, the volume overload would cause chamber dilatation, systolic dysfunction and symptoms of heart failure. $^{2}$

Over $10 \%$ of infants with large VSD would develop early signs of heart failure which include tachypnea, poor feeding, frequent respiratory tract infection and eventually failure to thrive. But not all cases of VSD will result in failure to thrive. ${ }^{3} \mathrm{~A}$ recent research indicates that more than a quarter of children with $\mathrm{CHD}$ are also obese or overweight. There are two main causes have been described as the cause of obesity in this population: lack of physical activity and diet which often include consumption of increased calories and foods with high fat and sodium content. These individuals have an increase risk of developing atherosclerosis and other cardiovascular disease in the future..$^{4,5}$

\section{CASE PRESENTATION}

A 19-year-old Balinese boy was brought to the emergency room due to chest pain, shortness of breath, orthopnea and cough, especially in night time that has lasted for 4 days. He had no family history of hypertension, diabetes mellitus, heart disease or asthma. He has a history of alcohol consumption for social occasion. Patients also have a history of fluctuate weight changing where patients have very low body mass index (BMI) when he was at early elementary school and become fat at late elementary school until junior high school. He stated that he was doing hard diet and exercise to become thin, but his heart condition getting worse, make him live a sedentary life and become obese. History of medication included spironolactone $50 \mathrm{mg}$ q.i.d, furosemide $40 \mathrm{mg}$ q.i.d, lisinopril $2.5 \mathrm{mg}$ q.i.d, nebivolol $2.5 \mathrm{mg}$ q.i.d and trimetazidine $35 \mathrm{mg}$ b.i.d. A physical examination done in the emergency room revealed a slightly elevated heart rate at 110 beats $/ \mathrm{min}$, blood pressure $114 / 50 \mathrm{mmHg}$, respiratory rate 18 time/min, body weight $110 \mathrm{~kg}$, body height $176 \mathrm{~cm}$ (BMI 35.5), oxygen saturation at $98 \%$ on $\mathrm{O}_{2}$ nasal canule 2 $\mathrm{I} / \mathrm{min}$, jugular venous pressure $5+4 \mathrm{cmH} 2 \mathrm{O}$, a grade 3 blowing pansystolic murmur at the apex, a rhales and a pretibial oedema.

An initial electrocardiogram showed sinus tachycardia, left axis deviation and biphasic $P$ wave in lead V2 (figure 1). Initial chest x-ray showed cardiomegaly and pulmonary oedema. Initial laboratory tests showed low haemoglobin count (10.95 g/dL), low hematocrit count (38.10\%), low MCV (79.26 fL), low MCH (22.78 pg), low MCHC (28.74 g/dL), and high RDW (17.44\%).

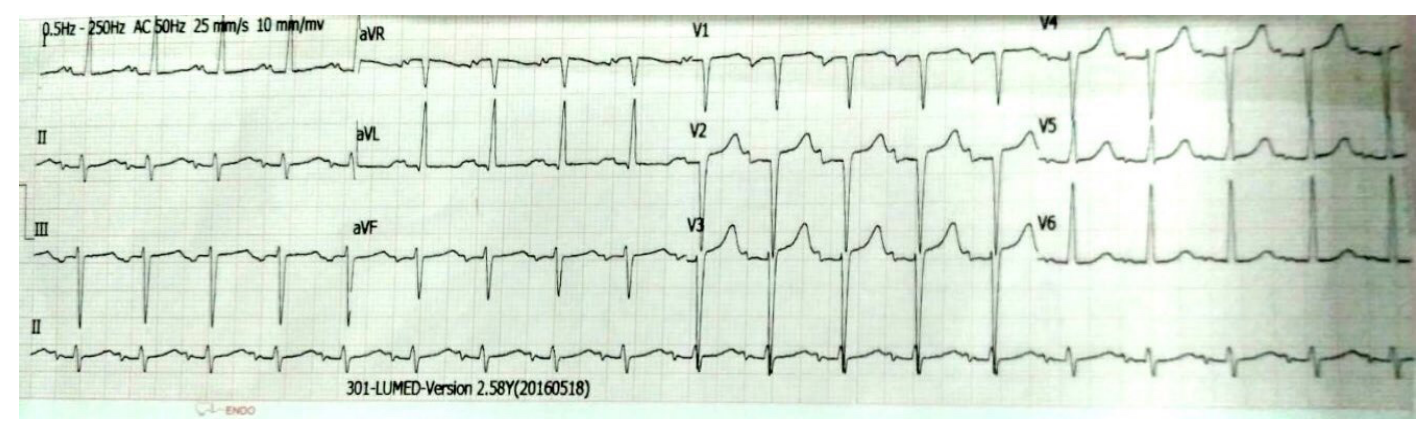

Figure 1. Patients electrocardiogram showed sinus tachycardia with heart rate 110 beat/ min, biphasic $p$ wave suggesting of left atrial enlargement, there was also left axis deviation suggesting left ventricular enlargement 
At the ward, an echocardiography examination was done and showed dilatation of right atrium (RA), right ventricle (RV), left ventricle (LV) and left atrium (LA) dimension. The LV interna diameter on diastolic phase (LVIDd) was 6.51 $\mathrm{cm}$, LA diameter was $4.8 \mathrm{~cm}$, RA ESA was 34.3 $\mathrm{cm}^{2}$, and RV base was $4.94 \mathrm{~cm}$. He also had low LV systolic function with LV ejection fraction (EF) $35 \%$, LV diastolic dysfunction with E/A ratio of 1.67, normal RV systolic function with TAPSE $2.0 \mathrm{~cm}$, global hypokinesia, severe aortic regurgitation due to prolapse right coronary cusp with descending aorta diastolic reversal (AR VC $0.6 \mathrm{~cm}$ and AR PHT 219 m.s), tricuspid regurgitation (TR maximal pressure gradient (PG) $53 \mathrm{mmHg}$, TR maximal velocity $364 \mathrm{~cm} / \mathrm{s}$ with hepatic vein systolic reversal), severe pulmonary regurgitation and
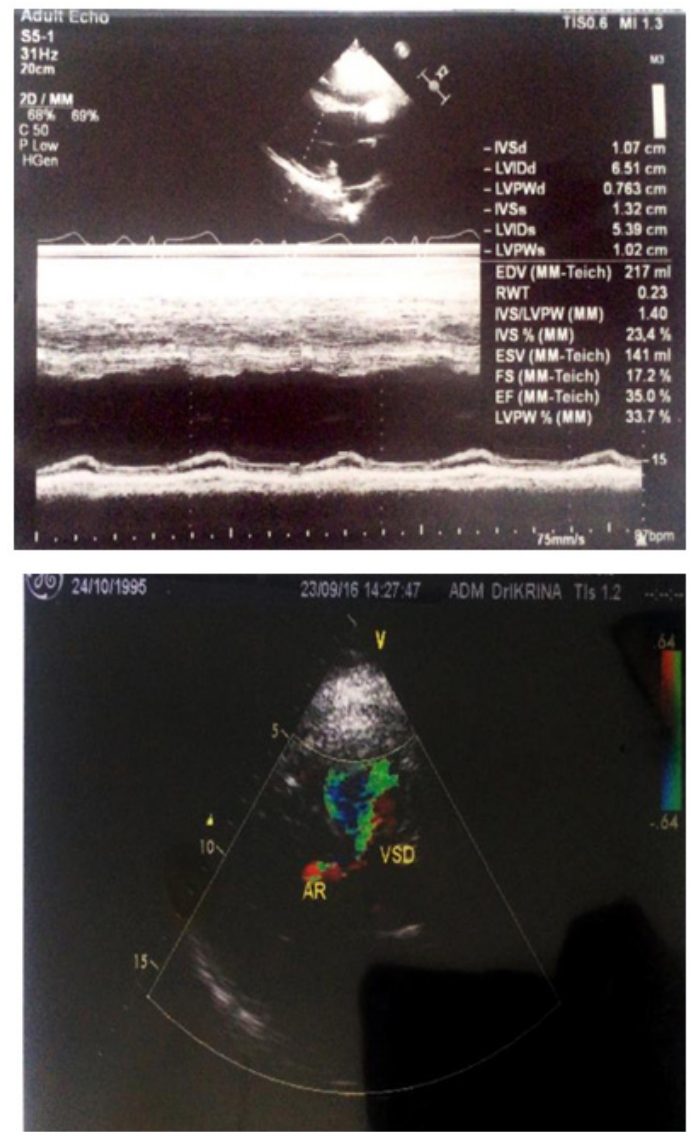

normal mitral valve. We found a supracristal VSD with left to right shunt in a parasternal short axis view, in the level of aorta near pulmonary valve. We did not find shunting in interventricular septum in parasternal view, apical five chamber view, and apical four chamber view. There was no atrial septal defect and patent ductus arteriosus in this echo result. The movement of all 17 segments of the heart was decreased (global hypokinetic). We suggested a pulmonary hypertension with estimated systolic pulmonary arterial pressure (sPAP) of $63 \mathrm{mmHg}$. This echocardiogram result had significant differences with his last echocardiography from 2016, where his LVEF was still $59.8 \%$, and TR max PG of $3.6 \mathrm{mmHg}$ (with estimated SPAP of $13.6 \mathrm{mmHg}$ ). Figure 2 shows the echocardiogram results.
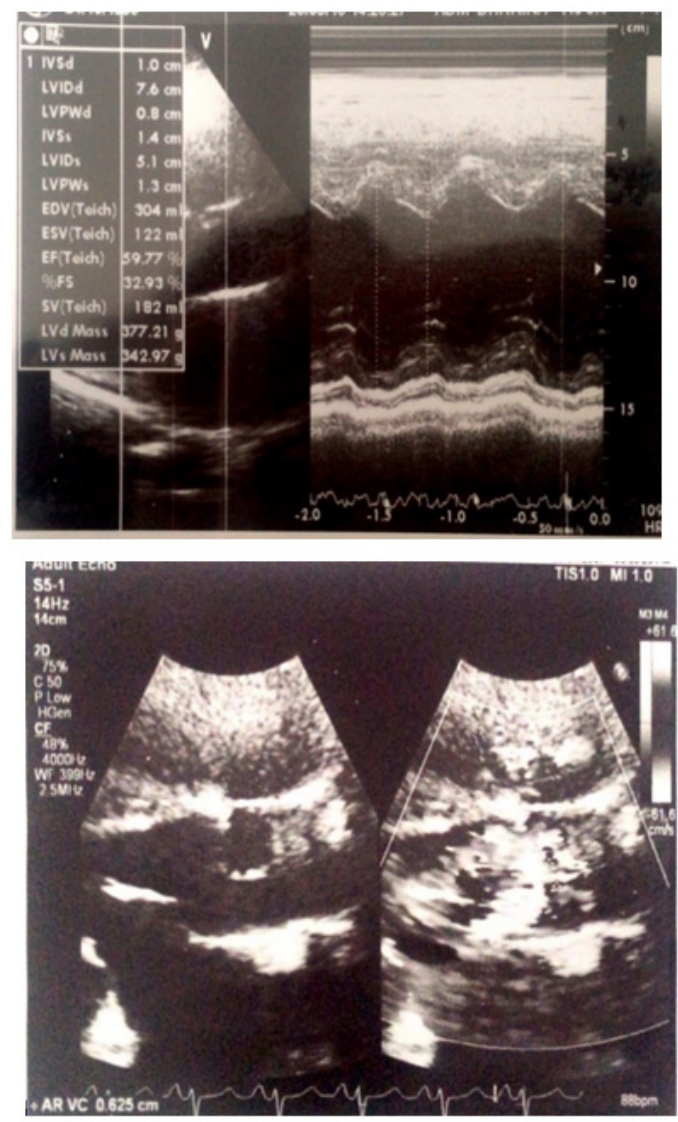

Figure 2. Left panel figures are patient echocardiogram in 2017 and right panel figures are patient echocardiogram in 2016. There is the decrease in LVEF from $59.8 \%$ to $35 \%$ from previous echocardiogram to newer echocardiogram. We also can observe the supracristal VSD. 
The diagnosis of acute decompensated heart failure (ADHF) profile $B$ caused by VSD was made. The patient was treated with intravenous $\mathrm{NaCl} 0.9 \%, \mathrm{O}_{2}$ nasal canule $2 \mathrm{l} / \mathrm{m}$, intravenous bolus of furosemide $100 \mathrm{mg}$ then continued with intravenous drip furosemide $5 \mathrm{mg} /$ hour, spironolactone $50 \mathrm{mg}$ q.i.d, and ramipril 2.5 mg q.i.d. Patient also presented with dyspepsia and was treated with sucralfat syrup $10 \mathrm{ml}$ t.i.d and lansoprazol $30 \mathrm{mg}$ q.i.d. We plan to do a pulmonary artery $\mathrm{O}_{2}$ responsiveness test in this patient, and if the result is positive, we plan to perform a VSD closure for this patient.

\section{DISCUSSION}

Obesity in Congenital Heart Disease (CHD)

Patients with CHD usually have a lower BMI than normal healthy child, but it does not mean that they are immune to obesity. Most people with $\mathrm{CHD}$ is restricted from participation in physical activity that may "stress the heart". Their parents also tend to feed high calorie formulas because they think more weight children are safer and less fragile. ${ }^{3,4}$ A study conducted by Shustack et al.(2012) found that $8 \%$ of children with CHD have overweight and obesity, and they tend to be a boy rather than a girl. ${ }^{4}$ This condition can happen because of the restriction of physical activity or carry the stigma of heart disease where they may not be encouraged to participate in physical activity and live a relatively sedentary lifestyle. ${ }^{6}$ About $41 \%$ of parents were unable to identify their children activity restrictions. There is significantly fewer males with CHD participated in vigorous activity because of their parents fear of the damage heart. ${ }^{4}$ There are also a contribution from cardiologist to discuss about diet, nutrition and physical activity of patients with CHD.

Only $63 \%$ of pediatric cardiologist discussed about the issues, another study found low rates of patients weight and diet counseling among CHD's patients and cardiologist that lead to miss perception among parents that will make them give their child more calories while restricted their child activities. ${ }^{3,6}$ The CHD patients themselves show low rates of interest in physical activity. A study conducted by Dotje et al. (2014) showed that $69 \%$ of $\mathrm{GUCH}$ patients do not want to participate an exercise program. About $32 \%$ of patients who do not want to participate in physical activity fear of disease related symptom while $24 \%$ just lack of interest in exercise. About $43 \%$ of them were satisfied with their physical fitness and $38 \%$ of them stated that they have lack of time to do the exercise. ${ }^{6}$

\section{Ventricular Septal Defect}

Ventricular septal defect (VSD) is the most common form of CHD. The prevalence of VSD in newborn babies is up to $5 \%$ by screening with highly sensitive colour doppler echocardiography although mostly are tiny muscular defects that disappear during the first year of life. VSD can be classifed into four main categories according to their location : perimembranous/conoventricular, subpulmonary/conotruncal, supracristal/doubly committed, muscular and atrioventricular canal/ inlet. ${ }^{1}$ Muscular defects are located within the muscular septum and they are surrounded by muscular rims. Perimembranous defects open into the right ventricle where the subpulmonary outflow tract turns superiorly relative to the atrioventricular junction. Doubly committed (subarterial or supracristal defects) lies caudal to the pulmonary valve in the infundibular portion of the right ventricular outflow tract. ${ }^{8}$ The location of the supracristal VSD with its close proximity to the aortic valve, accounts for the common development of right coronary cusp (RCC) prolapse with this defect. The absence of muscular septum below the adjacent aortic valve cusp is implicated because this results in unopposed downward force on the cusp during diastole, which progressively pull aortic valve tissue, especially RCC, through a venturi effect. ${ }^{7,8}$ Venturi effect is defined by reduction 
in fluid pressure that results when a fluid flows through a constricted section. Recognition of the venturi effect as the most important mechanism in the pathogenesis of aortic valve prolapse (AVP) will aid in identification of patients at risk for development of aortic insufficiency and will predict both those patients in whom surgery is indicated as well as the timing of surgical intervention. $^{8}$

\section{Pulmonary Hypertension in VSD}

Pulmonary hypertension $(\mathrm{PH})$ is defined by increased in mean pulmonary arterial pressure (PAPm) $\geq 25 \mathrm{mmHg}$ at rest as assessed by right heart catheterization (RHC). On the other hand, pulmonary arterial hypertension (PAH) describes a group of $\mathrm{PH}$ patients characterized haemodynamically by the presence of precapillary $\mathrm{PH}$, defined by a pulmonary artery wedge pressure (PAWP) $\leq 15 \mathrm{mmHg}$ and a pulmonary vascular resistance $(P V R)>3$ Wood units (WU) in the absence of other causes of precapillary $\mathrm{PH}$ such as $\mathrm{PH}$ due to lung diseases, chronic thromboembolic pulmonary hypertension (CTEPH) or other rare diseases. ${ }^{9} \mathrm{~A}$ restrictive VSD, defined as those with an orifice dimension less than or equal to $25 \%$ of the aortic annulus, would no cause pulmonary hypertension nor left ventricular volume overload. But on the other hand, a larger VSD generally cause moderate to larger left-to-right shunts with left ventricular overload and if remain uncorrected may cause severe pulmonary hypertension caused by longstanding obstructed pulmonary flow. With progressive pulmonary arterial hypertension, the right ventricular pressure can reach systemic levels leading to reversal of the shunt which would cause hypoxemia and cyanosis; this condition is known as Eisenmenger syndrome. ${ }^{10}$

Management of Pulmonary Hypertension in VSD

Patients with pulmonary hypertension usually associated with RV failure. High resistance of the lungs causes the blood from RV difficult to enter pulmonary artery. It will causing overload of the RV, dilatation of RV wall, also decreasing contraction and function of the RV. ${ }^{5,7}$ Right ventricle failure affected blood volume that will enter LA. Small amount of blood volume which will enter the left chamber also impaired diastolic function of LV, and decrease cardiac output, making the systemic perfusion decrease and the heart more prone to ischemic because of flow decrease to the coronary artery during systolic phase. ${ }^{5}$ Pulmonary hypertension affects oxygenation of the blood. High resistance of the lung and alveolar will decrease the amount of deoxygenated blood that will be oxygenated in alveolus. It directly lowers systemic oxygenation. ${ }^{7}$ Low oxygenation and perfusion affect Quality of Live (QoL) in patients with $\mathrm{PH}$, they tend to have a lower capacity in exercise, also limitation in daily activity. ${ }^{8,10,12}$ In our case, patient almost sleep or rest for the whole day and experience a great dyspnea in every activity, it also affected his social live where he could not go out with his friends anymore. It also had a contribution to his obesity where his sedentary life made him gaining weight more and more.

Patients with $\mathrm{PH}$ have several problems to undergo surgical procedure especially cardiac surgery procedure. Patients with $\mathrm{PH}$ relatively more prone to ischemic during the surgery because of it natural hemodynamic changes and anesthesia effect in depressing myocardial contraction during the surgery. ${ }^{9,10,13}$ Patients undergoing cardiac surgical repair showing mortality rates of up to $25 \%$, the risk of RV dysfunction and ischemia is significant particularly after extracorporeal circulation is stopped. Patients undergoing cardiac surgery also experience pulmonary vasoconstriction correlates with the induced endothelial injury which can make the patient more prone to have a thrombus and stroke after surgery. ${ }^{10,13}$ Preoperative hemodynamic goals for $\mathrm{PH}$ are MAP 
$>55-60 \mathrm{mmHg}, \mathrm{SBP}>80 \mathrm{mmHg}, \mathrm{SvO}_{2} 92 \%-100 \%$, RAP $<10 \mathrm{mmhg}$, MPAP $<35 \mathrm{mmHg}, \mathrm{PVR} / \mathrm{SVR}$ $<0.5, \mathrm{PCWP} 8-12 \mathrm{mmHg}$, and $\mathrm{Cl}>2.2 \mathrm{~L} / \mathrm{min} / \mathrm{m}^{2} .{ }^{9}, 14$ Our case also had a high risk for cardiac surgery for his VSD closure. If the wall of pulmonary artery had already been stiff and did not respond to the oxygen, it indicated that his mortality and risk for $\mathrm{PH}$ crisis were high. ${ }^{15,16}$ To test the viability of the pulmonary artery, its needed $\mathrm{O}_{2}$ challenge test with cardiac catheterization . Vasodilator testing perform using nitric oxide and oxygen as a primary agent and administered via inhalation with concentration 20 or 40 parts per million. Vasoreactivity defined by a decrease in MPAP by $10 \mathrm{mmHg}-40 \mathrm{mmHg}$ during the test. The decrease of $\mathrm{mPAP}>40 \mathrm{mmHg}$ and $\mathrm{PVRI}>8$ was considered inreactive result, and have a risk to increase RV pressure after surgical repair. 16,17,18 His VSD which have a shunt direction from right to left help to reduce RV overload also decreased $\mathrm{RV}$ pressure and increased preload for left heart chamber. If his pulmonary artery wall had already been unresponsive during $\mathrm{O}_{2}$ challenge test, the closure of the VSD will increase RV pressure, decrease LV preload also cardiac output which render his prognosis getting worse. ${ }^{17,18}$

Effect of Obesity in Management and Prognosis of VSD with Pulmonary Hypertension

The current consensus of whether to close the shunt or not is determined pulmonary vascular resistance index (PVRi). The decision to close the shunt is done when PVRi is $<4$, and the closure is not done when PVRi is $>8$, if PVRi is between 4-8 then the patient is individually evaluated. ${ }^{17,18}$ But there is still limited data on the usefulness of the vasoreactivity test. ${ }^{19}$

Several studies have been conducted examining the effects of obesity with treatment of congenital heart disease. A multicenter retrospective cohort study of extreme low and high BMI association of adverse perioperative outcomes in patient undergoing congenital heart disease operation has been done. A study conducted by O'Byrne et al. (2017) concluded that obesity was associated with increased risk of composite adverse outcomes that are independent of other risk factors. The risk acquired seems to be different between younger population (children, adolescents, and young adults) with congenital heart disease and adults with acquired heart disease, with the younger population experienced shorter duration of morbidity. ${ }^{14}$ The risk associated with obesity and congenital heart disease does not mean decreasing BMI will give better outcomes, further study is warranted. Other study concluded obesity did not affect the mortality and short term outcomes with adult population, but there is an increase of renal impairment on obese severe congenital heart disease patient. ${ }^{20}$ Patient with congenital heart disease have an increased risk for developing metabolic syndrome, and may be because of several risk factors including exercise restriction and differing nutritional strategies in infancy. ${ }^{19,20}$ In our patient, the risk for metabolic syndrome is augmented by his obesity. Obesity in congenital heart disease have also been seen to have lesser exercise time even with a milder disease severity. ${ }^{20}$

\section{CONCLUSION}

Patients with CHD do not always have low $\mathrm{BMI}$, some of them tend to have higher BMI than average due to limitation on physical activity. The CHD patients with obesity have higher risk to acquire early coronary artery disease and metabolic disease. Obesity is increased risk of adverse outcome due to their disease.

\section{ACKNOWLEDGEMENTS}

In arranging this paper, a lot of people and organization have provided their help and support for authors. The appreciation goes to the patient who agree to put his cases into 
publication, Integrated Heart Service, Sanglah Central Hospital, Bali that provided us access to our patients in this report, Kelompok IImiah Hippocrates $(\mathrm{KIH})$ who always support us, and also our beloved teachers who always guided us in the process of making this paper.

\section{REFERENCES}

1. Berg D.D., Brown D.W. 2010. Congenital heart disease. In: Lilly LS, editor. pathophysiology of heart disease. 5th ed. Lippincott Williams \& Wilkins; pp. 361-385.

2. Webb G.D., Smallhorn J.F., Therrien J., Redington A.N. 2015. Congenital heart disease. In: Mann DL, Zipes DP, Libby $\mathrm{P}$, Bonow RO, editors. Braunwald Heart Disease: A Textbook of Cardiovascular Medicine. 10th ed. Elsevier Inc; pp. 13921443.

3. Pinto N.M., Marino B.S., Wernovsky G., de Ferranti S.D., Walsh A.Z., Laronde M., et al. 2007. Obesity is a common comorbidity in children with congenital and acquired heart disease. Pediatrics, 120:e1157-1164.

4. Shustak R.J., Mcguire S.B. 2012. Prevalence of obesity among patients with congenital and acquired heart disease. Pediatr Cardiol, 33:8-14.

5. Barbiero S.M., Sica C.D.A., Schuh D.S., Cesa C.C., Petkowicz R.D.O., Pellanda L.C. 2014. Overweight and obesity in children with congenital heart disease : combination of risks for the future ? BMC Pediatr, 16;14:271.

6. Swan L., Hillis W.S. 2000. Exercise prescription in adults with congenital heart disease: a long way to go. Heart, 83:685-687.

7. Penny D.J., Vick G.W. 3rd. 2011. Ventricular septal defect. Lancet, 377(9771):1103-1112.

8. Tweddell J.S., Pelech A.N., Frommelt P.C. 2006. Ventricular septal defect and aortic valve regurgitation: pathophysiology and indications for surgery.Semin Thorac Cardiovasc Surg Pediatr Card Surg Annu, 9:147-152.

9. Galiè N., Humbert M., Vachiery J-L., Gibbs S., Lang I., Torbicki A., et al. 2016. 2015 ESC/ERS Guidelines for the diagnosis and treatment of pulmonary hypertension. Eur Heart J, 37:67-119.

10. Tuder R.M., Stacher E., Robinson J., Kumar R., Graham B.B. 2013. Pathology of pulmonary hypertension. Clin Chest Med, 34:639-650.

11. Dontje M.L., Feenstra M., de Greef M.H., Nieuwland W., Hoendermis E.S. 2014. Are grown-ups with congenital heart disease willing to participate in an exercise program ? Congenit Heart Dis, 9:38-44.

12. Torres Dde F., Zin W.A., Lopes A.J., Vigário Pdos S., Garcia M.I., Waetge D., et al. 2015. Association between hemodynamic profile, physical capacity and quality of life in pulmonary hypertension. Arq Bras Cardiol, 104:387-393.

13. Minai O.A., Yared J-P., Kaw R., Subramaniam K., Hill N.S. 2013. Perioperative risk and management in patients with pulmonary hypertension. Chest, 144:329-340.

14. O’Byrne M.L., Kim S., Hornik C., Yerokun B., Matsouaka R., Jacobs J., et al. 2017. Effect of obesity and underweight status on perioperative outcomes in patients with congenital heart disease: an analysis of data from the Society of Thoracic Surgeons Congenital Heart Surgery Database. Circulation, 136(8):704-718.

15. McGlothlin D., Ivascu N., Heerdt P.M. 2012. Anesthesia and pulmonary hypertension. Prog Cardiovasc Dis, 55:199-217.

16. Apitz C., Hansmann G., Schranz D. 2016. Hemodynamic assessment and acute pulmonary vasoreactivity testing in the evaluation of children with pulmonary vascular disease. Expert consensus 
statement on the diagnosis and treatment of paediatric pulmonary hypertension. Heart, 102 Suppl 2:ii23-9.

17. Grignola J.C. 2011. Hemodynamic assessment of pulmonary hypertension. World J Cardiol, 3(1):10.

18. Zaidi A.N., Bauer J.A., Michalsky M.P., Olshove V., Boettner B., Phillips A, et al. 2011. The impact of obesity on early postoperative outcomes in adults with congenital heart disease. Congenit Hear Dis, 6:241-246.

19. Deen J.F., Krieger E.V., Slee A.E., Arslan A., Arterburn D., Stout K.K., et al. 2016. Metabolic syndrome in adults with congenital heart disease. J Am Heart Assoc. 5:1-8.

20. Kuehl K., Tucker A., Khan M., Goldberg P., Anne Greene E., Smith M. 2015. Overweight predicts poorer exercise capacity in congenital heart disease patients. IJC Hear Vasc, 9:28-31. 